\title{
ファジィ適応コントローラを用いたスポット溶接機の実時間制御
}

\author{
非会員荒木獻次（埼玉大学工学部） \\ 学生員陳 星橋 (埼玉大学大学院)
}

\section{On-line Control of a Spot Welding Machine by Using a Fuzzy Adaptive Controller}

\author{
Kenji ARAKI and Xingqiao CHEN (Saitama University)
}

\begin{abstract}
This paper describes a control scheme for on-line control of a spot welding machine. From the simulation of the soft-steel welding process by constant current, constant power and variable power methods with numerical analysis by FEM, nugget sizes etc. obtained are compared for these three methods. Variable power method is the best one for obtaining the biggest nugget and is used here as a reference (welding energy) model. And a fuzzy adaptive controller(FAC) instead of an usual fuzzy controller(FC) is developed and used for the improvement of the control accuracy of the spot welding machine. The membership functions of the fuzzy adaptive controller will be modified in real time with the adaptive algorithms according to distinct operating stages and working environment. Combining the reference energy model and FAC, a model reference fuzzy adaptive control(MRFAC) scheme is developed. The results of simulation and experiments with a dummy circuit of the spot welding system show that it is possible to control welding energy with on-line. Simulations also show that the control performance of the welding system with FAC becomes better than that with FC. And the experimental result indicates that the MRFAC system has also robustness for parameters changes, welding stage changes and disturbance.
\end{abstract}

キーワード：規範モデル，適応制御，ファジィ制御，ファジィ適応コントローラ，抵抗スポット溶接

\section{1.はじめに}

抵抗スポット溶接法は薄板鋼板の高能率で信頼性 のある接合方法として，自動車をはじめ鉄道車輌， 各種板金、家電製品などの工業製品の他，スポーツ 用具, 装飾品など金属の接合に幅広く使用されてい る.これら工業製品の外観と溶接の質向上のために は，スポット溶接機の知能化と実時間制御の開発研 究が必要である1). しかし，今までのスポット溶接 機制御のほとんどがオフライン制御で定電流制御で ある。近年，松山らによって溶接プロセスのシミュ レーションが行われ，定電力制御が定電流制御に比 ベて，溶接可能電流領域が広くなり，この効果が厚 板ほど顕著となることが明らかにされている2).

本研究は，先す，松山と西口の抵抗スポット溶接 のナダット数值計算モデル2),3 を用い，有限要素法 によるシミュレーションにより，投入溶接エネルギ -一定のもとに, 定電流, 定電力及び可変電力の各 制御の場合に得られるそれぞれのナグット径を算出 し，各制御をナゲット径のサイズの面から比較し， 可変電力制御が良いことを示す。この可変電力特性 は，初期に大きな溶接パワ一を投入し，後は指数関 数状に減少させるものである。

次に，この可変電力特性を規籍モデル（エネルギ
一モデル)として，その出力をスポット溶接のプロ セス制御系の目標值としたモデル規範形ファジィ適 态制御系を構成する。ここでは，正確な数学モデル で記述し難い溶接プロセスに対して、ファジィ制御 を導入する．しかし，普通のファジィコントロー ラ(FC)ではパラメータが固定されているので, 制御 精度があまり良くない。そこで，制御精度を改善す るため，適応的なアルゴリズムで、ファジィコント ローラのパラメータをオンラインで修正することを 試みる.これをファジィ適応コントローラ(FAC) と 呼ぶことにする。ここでは，FACの制御システムと 普通のFCを用いたシステムとをシミュレーション により比較し，更に，ダミ一回路を用いた実験結果 について述べる.

\section{2. 溶接プロセスと規範エネルギーモデル}

抵抗スポット溶接の制御システムの電気等価回路 を図 1 に示す. 被溶接板の等価電気特性はりークの 等価抵抗 $\left(\mathrm{R}_{\mathrm{W}}\right)$ とインダクタンス $\left(\mathrm{L}_{\mathrm{W}}\right)$ の直列接続され た等価インピーダンス $\left(Z_{\mathrm{w}}\right)$ である。この等価抵抗の ジュール発熱によって, 溶接部は加熱され, ナゲッ トが造られる。 


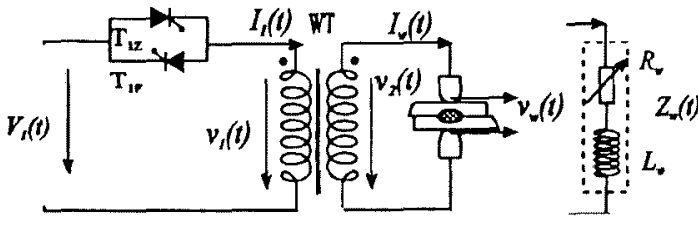

図1 スポット溶接システムの等価回路

Fig. 1 Equivalent circnit of a spot welding system

松山，西口 ${ }^{2), 3)}$ の溶接部の温度を推定する有限要 素法による数值計算モデルを用い（図2），溶接ナ ゲットのサイズを計算する.ここでは，溶接板に投 入する熱量（投入溶接総エネルギーは一定とする） は, 溶接電流 $I_{w}(t)$ と電極間電圧 $V_{w}(t)$ で決まるエネル ギー，あるいは，等価抵抗のジュール発熱量である。

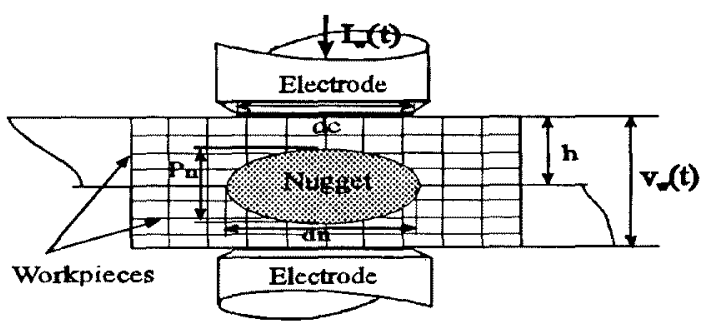

図2 溶接ナダットの数值計算メッシュ Fig. 2 Diagram of calculating nugget of a spot welding

被溶接板に投入するエネルギーとナゲットサイズ の関係を検討するにあたって，次のことを配虑する， 1)発熱密度を適度にする. (a)溶接初期には，接触径 の変化が激しく，発熱量あるいは電流密度が足らな いとナゲットの形成が難しい，(b)電流密度が高す ぎると，電極と板の間の散り，板閒散りや表面のく ぼみが生じる。(c)溶接後期には，発熱密度が高い と，溶込みが大きくなり，表面の美観や電極の毒命 に影響がでる．2)全プロセスを通じて，できるだけ 熱損失を小さくして，エネルキー效率を高くする. 以上より，溶接初期にはナダットを早く形成させる ために大きなパワーを投入する，溶接中期には熱損 失が小さく，ナダットサイズを增大させ続けるため， 大き目なパワーを投入する。また，溶接終期には， ナダットの溶込みが大き過ぎず，電極の温度が高く なり過ぎないように，小さ目のパワーを投入する。

以上の上うな可変電力特性の溶接規籍エネルギーモ デルを次式で与えることにする.

$$
W(t)=W_{0}(h)\left(1-e^{-a(h) \frac{8 k}{d^{2} t}}\right)
$$

$$
\text { ここでは }
$$

$\mathrm{d}$ : 理想のナゲット径, $\mathrm{d}=(5-6) \sqrt{h}(\mathrm{~mm})$

$\mathrm{h}:$ 溶接板の厚さ $(\mathrm{mm})$

$\mathrm{k}$ : 熱拡散究 $\left(\mathrm{mm}^{2} / \mathrm{s}\right), \alpha(\mathrm{h})$ : 補正係数 $\alpha(\mathrm{h})=2 \mathrm{~h} \pm 0.5$ $\mathrm{W}_{\mathrm{o}}(\mathrm{h})$ : 投入するエネルキー $(\mathrm{kWs})$ (ナゲットを造る のに要するエネルギーと損失エネルギーを考えて求
める)

図3は式(1)の規籍エネルギーモデルによる溶接と 普通の定電流溶接あるいは定電力溶接を比較するた めに求めた溶接ナゲットの径と溶け込みを示す。こ の結果をみると，式(1)の可変電力特性の場合は， 他に比べて，同じ投入総エネルギーに対して，大き なナダット径が得られること, また, ナダットの溶 込みが大き過ぎず適当な值であることが分かる。

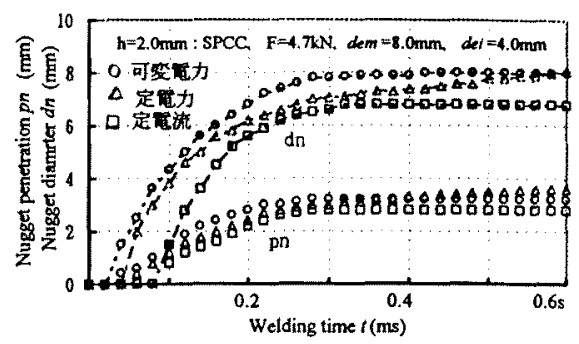

図3 各制御法によるナゲットの径と溶け込み

Fig. 3 Nugget penetration and diamrter with the diffirent control methods

また, 溶接部の接触状態や温度の変化によって, 等価抵抗が激しくかつ不確定に変化し，ジュール発 熱量と加熱効果がかなり変化し, 溶接システムの入, 出力特性も変化する ${ }^{4)}$. 軟銅のスポット溶接シミュ レーションの温度と接触佳より推定したワーク等価 抵抗を図4に示寸.一例として, 板厚 $h=2.0 \mathrm{~mm} の$ 軟銅, 電極直径 $d_{e}=8.0 \mathrm{~mm}$ 加圧力 $F=4.7 \mathrm{kN}$, 溶接 時間 $t_{w}=0.6 \mathrm{~s}$ の溶接プロセスに対し，推定した抵抗 值 $R_{s}=82.4 \mu \Omega, R_{p}=183.5 \mu \Omega, R_{w}=108.5 \mu \Omega$ である.

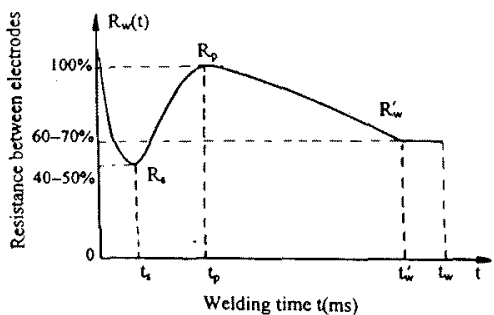

図4 軟鋼の溶接中の推定抵抗值

Fig. 4 Estimated resistance of soft steel at spot welding

徒って、スポット溶接のプロセスは多くの因子に よって多様な影響を受け，非線形，不確定であり， 楾形微分方程式で正確に記述するのは難しい，一般 に，スポット溶接は，溶接時間が 1 秒以下の場合が 多く，スポット溶接のバッチプロセスは非常に短時 間に終了し，この短時間の内にプロセスのパラメー 夕(例えほ，被溶接部の温度が常温から1800Kまで 変化する）が大幅に変動するので，状態変化が非常 に速いと考えられる。その間に等価抵抗が激しく変 化する，溶接の結果であるナゲットのサイズと溶け 
込みをオンラインで測るのは難しい，従って，通常 の制御理論を適用することは難しく，溶接機の実時 間制御も困難になっている5)。

本研究では、シミュレーションより求めたナゲッ トのサイズと被溶接板に投入した総エネルギーの関 係を考えて，実時間制御するために，ナダットのサ イズの代わりに被溶接板に投入したエネルギーを测 ることにする。この制御システムの入力も溶接エネ ルギーであり，出力は被溶接板（ワーク）の等価抵 抗に投入したエネルギーである。この溶接プロセス を三つの時間帯で分け，システムの特性を考察する。 図4に対応して，システムが立ち上がり，ナダット が未だ形成されていない時期を溶接初期 $t \in\left(0, t_{p}\right)$, 次にナゲットのサイズが增加している時期を浴接中 期 $t \in\left(t_{p}, t^{\prime}{ }_{W}\right)$, 溶接部の温度を保持する時期を溶 接終期 $t \in\left(t_{W}^{\prime}, t_{W}\right)$ と呼ふことにする。 この溶接規 範エネルギーモデルの出力を溶接システムの制御入 力として，被溶接板に投入するエネルギ一を実時間 制御することができる.

\section{3. ファジィ制御とファジィコントローラ}

\section{1 ファジィ制御系の概要}

ファジイ制御采の基本構成は，一般に，図 5 に示 すようなフィードバック系である。制御誤差e $(n T)$ とその微分值 $d e(n T)$ を取り込み, ファジィ推論の後, 操作量 $u(n T)$ が決められる。

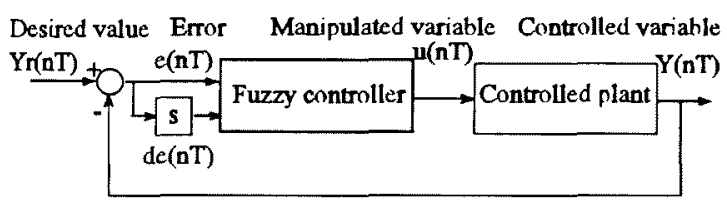

図5 ファジィ制御系のプロック線図

Fig. 5 Block diagram of a fuzzy control system

通常，この制御方式のアルゴリズムにおいては， PD(Proportional and Derivative Algorithm)制御が行わ れることが多い。すなわちPD制御における操作量 $u(n T)$ は偏差e $(n T)$ とその偏差の微分值 $d e(n T)$ を用いて, 次式のように記述される6).

$$
\begin{aligned}
& u(n T)=k_{P} e(n T)+k_{D} d e(n T) \\
& e(n T)=Y_{r}(n T)-Y(n T) \\
& d e(n T)=e(n T)-e[(n-1) T]
\end{aligned}
$$

ここで， $k_{P}$ は比例制御係数， $k_{D}$ は微分制御係数、 $Y_{r}(n T)$ は目標值, $Y(n T)$ はプラントの出力（制御量） である。

\section{2 ファジィコントローラの基本構成}

ファジィコントローラはファジィ化部，非ファジ イ化部，知識ベース及びファジィ判断部の四部分か
ら構成されている7).

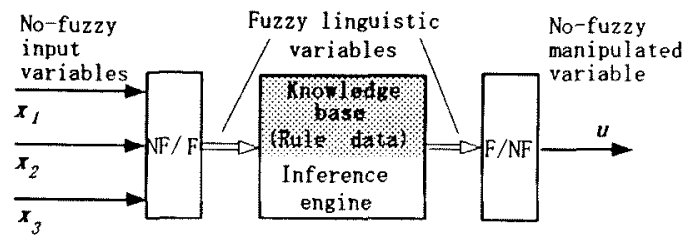

図6 ファジィコントローラのブロック線図

Fig. 6 Block diagram of a fuzzy controller

ファジィコントローラの知識ベースといわれる部 分には，制御ルール群が含まれている。このファジ イコントローラは制御ルール群の各If部（前件部） に記述されている状態を入力とし，Then部（後件 部）に記述されている操作量を出力として，操作量 を決定する多入力多出力の非線形要素としてみなす ことができる，たとえば，PD制御方式において， ファジィコントローラの入力e $(n T)$ とde $(n T)$ は-1 +1 の区間に正規化された状態量において，NB：負で 大, NM：負で中, NS：負で小， Z：ゼ口, PS：正 で大, PM：正で中，PB正で小，等のファジィ変数 で評価する．七つの三角形ファジィメンバシップ関 数(MF)を用いた例を図7に示す6),8).2 入力 $(e, d e)$ 1 出力 $(\boldsymbol{u})$ の場合, $i$ 番目のファジィ制御ルールは式 (5)で示される。

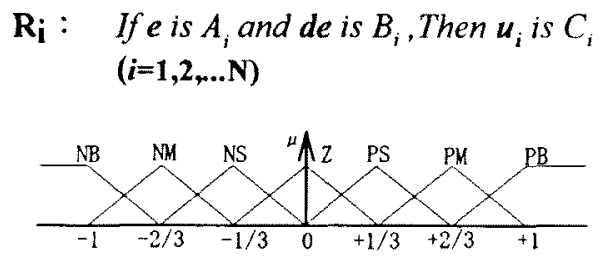

図7 久力変数のメンバシッブ関数

Fig. 7 Membership functions of input variables

以上のメンバシップ関数とファジィ制御ルールを 用いた場合，メンバシップ関数の定義域（区閒）は 固定されていて，ファジィ集合区間も変化しない。 過渡応答の誤差を小さくしようとすると，定常状態 における安定度が損なわれ，定常状態の安定性を良 くしようとすると過渡状態の誤差が大きくなること がある．特にシステムパラメータがよく変わる溶接 プロセスの場合には、目標值に対して，常に良好な 応答を得ることは難しい9．したがって，ここでは 溶接ブロセスにおいて，溶接の各段階に要求される 制御精度に对応して，ファジィコントローラのパラ メータを適灾的に修正する一種のファジィ適応コン トローラを開発することにする。

$$
\text { 4. ファジィ適応コントローラ設計 }
$$

ここでは，制御システムの偏差とその微分做及び 
溶接プロセスに応じて，ファジィ集合区間を調節し， 更にファジィコントローラ制御出力ダインを調節す るような適応コントローラ（以下，これをファジィ 適応コントローラ(FAC) と呼ぶ) について述へる。 FACのメンバシップ関数は偏差, 偏差の微分値およ び溶接プロセスによって自動的に修正される，すな わち,このメンバシップ関数の集合区間が制御対象 の状態量によって泣応アルゴリズムにしたがってオ ンラインで自動修正され, FACの入力の定義域が変 化する。溶接の全プロセスを三つの時間帯 $t_{i}$, 即ち 溶接初期 $t \in\left(0, t_{1}=t_{p}\right)$, 中期 $t \in\left(t_{1}, t_{2}=t_{w}\right)$, および終 期 $t \in\left(t_{2}, t_{w}\right)$ の溶接プロセス動特性に依存して変化す る許容偏差（適応条件式）を考えこのファジィ集 合のメンバシップ関数を式(6)のように変化させる.

$$
\left.\begin{array}{l}
f(t, e, d e)=1-e^{-\gamma \sqrt{\alpha \bar{e}(t)^{2}+\beta \overline{d e}(t)^{2}}} \\
t \in\left(o, t_{1}\right) ; \gamma=\gamma_{1} ; \quad \bar{e}(t)=\bar{e}(o), \overline{d e}(t)=\overline{d e}(o) \\
t \in\left(t_{1}, t_{2}\right) ; \gamma=\gamma_{2} ; \quad \bar{e}(t)=\bar{e}\left(t_{1}\right), \overline{d e}(t)=\overline{d e}\left(t_{1}\right) \\
t \in\left(t_{2}, t_{w}\right) ; \quad \gamma=\gamma_{3} ; \bar{e}(t)=\bar{e}\left(t_{2}\right), \overline{d e}(t)=\overline{d e}\left(t_{2}\right)
\end{array}\right\}
$$

ここで定数 $\gamma_{1}>\gamma_{2}>\gamma_{3}, \alpha$ と防荷定数である. $f(t, e, d e):$ ファジィ集合区間を表す関数

$t_{1}:$ 溶接プロセス中期の開始時刻

$t_{2}:$ 溶接プロセス終期の開始時刻

$t_{w}:$ 溶接プロセス終了の時刻

$\bar{e}:$ 設定された出力偏差(誤差)の許容值

de : 設定された偏差の微分の許容值

溶接初期には, 溶接板の等価抵抗が急激に変化し、 ナゲットが末だ形成されておらず，偏差が多少大き くてもエネルギー損失は小さく溶接の質に与える影 響が小さいので，かなりの誤差が許容される。それ からパワーが減少してある程度小さくなるまでの溶 接中期においては，誤差が溶接の質に影響するので, 許容誤差は小さくなる. それ以後の終期においては, 誤差はエネルギー損失とナダットの溶け込みに影響 するので，あまり許容誤差は大きくできない。

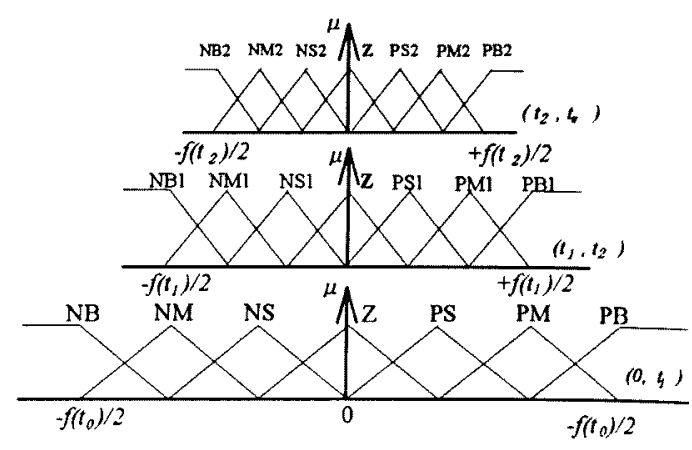

図8 FACのメンバシップ関数

Fig. 8 The Modified MF of FAC

以上の要求から，メンバシップ関数を図8のように 修正する. 図 8 においいて $1 \geq f\left(t_{0}\right)>f\left(t_{1}\right)>f\left(t_{2}\right)>0$ で ある。

\section{5. 抵抗スポット溶接機への応用}

2章で求めた可変電力の溶接規範エネルギーモデ ルと4章で述べたファジィ適応コントローラを組み 合わせ用いてスポット溶接機の新しいモデル規範形 ファジィ適応制御システムを構筑する ${ }^{10)}$.

\section{1 溶接機のファジィ適応制御系}

ここでは，規範エネルギーモデル，式(1)が溶接 システムの目標値よなる，溶接電流之電極問電圧を 测って投入のエネルギーをオンライン計算し、その 目標值に従って，投入のエネルギーを制御する。し かし，この規範モデルを構筑するにあたっては，溶 接機の電力容量から決まってくるパワーの制限と電 流の制限を溶接プロセスの各階段（溶接初期，中期， 終期）毎に配慮する必要がある。溶接の最適条件は， これらの制限を考えて決める必要がある。溶接機の 電気容量を考え，溶接プロセスの各段階に対応して 電流制限值 $I_{i}$ を配虑する $(i=1,2)$. 規籍エネルギーモ デルのもう一つの出力の最大值 $I_{m}(t)$ を考える.

$$
I_{m}(t)= \begin{cases}I_{1} & t \in\left(0, t_{1}\right) \\ I_{2} & t \in\left(t_{1}, t_{w}\right)\end{cases}
$$

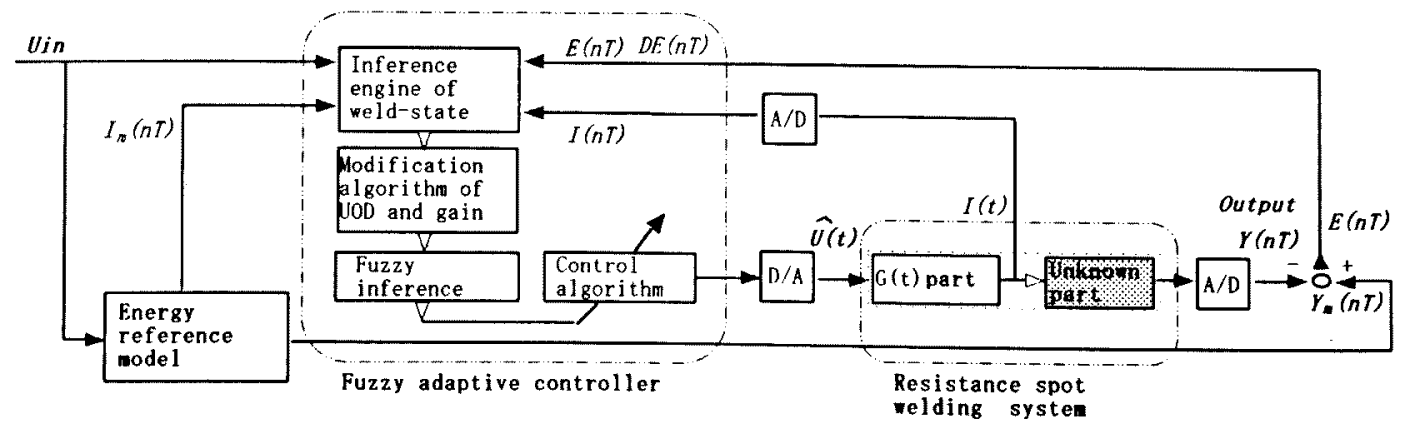

図9 スポット溶接機のファジィ適応制御系

Fig. 9 Fuzzy adaptive control for the spot welding system 
図9は，規籍モデルとFACを用いたスポット溶接 機のモデル規籍形ファジィ適态制御系を示す. FAC の出力はサイリスタの制御回路の入力となっていて, 溶接の電流とエネルギーの実時間制御が行える、制 御対象は図1のように, サイリスタの制御入力 $\hat{U}(t)$ のところから，ナゲットを造るために費やされる溶 接エネルギー $Y(n T)$ までの電気系である、即ち、図 9 中の $G(t)$ はサ:・スタと溶接トランス部分の伝達特 性を示し, 不確定部分は被溶接板の等価抵抗とイン ダクタンスである. $Y_{m}(n T)$ と $Y(n T)$ はそれぞれ規籁 エネルギーモデルの出力と実際の溶接エネルギー出 力 (溶接電流と電極間電圧を测定し, 等価抵抗を求 めて算出）である. 図9では, 規範エネルギーモデ ル, FACなどはコンピュータで実現している。

5.2 ファジィ適応コントローラの実現

制御を実時間で行うために，高速化や低価格化を 目指し，FACのアルゴリズムによる計算を事前に計 算しておき，ルックアップテーブルとしてメモリに 保存しておく方法を用いている゙11. 溶接の全プロセ スを初期，中期及び終期の3段階に分け，それぞれ に対応して3種類のファジィ集合空間とメンバシッ プ関数を設けているので，ルックアップテーブルは 全部で3頁になり，その中からFACの出力（操作量 $u(n T) ）$ が得れる。 また，規籍エネルギーモデルか らの出力電流 $I_{m}(n T)(\mathrm{kA})$ と溶接電流 $I(n T)(\mathrm{kA})$ の 差dI $(n T) \quad(\mathrm{kA})$ が変わる度にゲイン $\hat{C}_{u}(n T, d I)$ も再調 節し，操作量を修正する必要がある. 即ち, ルック アップテーブルから読み取った操作量 $u(n T)$ はその ままサイリスタを制御するのではなく，先ず $d I(n T)$ を次式で計算する。

$$
d I(n T)=I_{m}(n T)-I(n T)
$$

$\hat{C}_{u}(n T, d I)=(1-\eta|d I(n T)|) C_{u}$

whan $n$ T $\left.E 0, t_{1}\right)$ or $\left(t_{1}, t_{2}\right)$, if $\begin{cases}d I(n T)>0 \text { than } \eta=0 \\ d(n T)<0 \text { than } \eta=03 \text { × } 0.15\end{cases}$ when $n T \Theta\left(t_{2}, t_{w}\right)$, if $e(n T)<0$ then $\hat{C}_{w}(n T, d)=\frac{C_{u}}{(1+3 e(n T) \mid)}$

ここで，ゲインの初期値 $C_{u}=2.0, \eta \in(0,1)$ は保数で ある。修正した操作量 $\bar{U}(n T)$ は次式で求められる。

$$
\widehat{U}(n T)=\widehat{C}_{u}(n T, d I) u(n T)
$$

以上のように，式(6)により溶接の各段階でメンバ シップ関数を修正し，式(9)によりFACのゲイン $\hat{C}_{u}(n T, d I)$ を算出し，これを式(10)に代入すること により操作量を修正して、システムに適応性を持た
せるようにしてあるＦACの制御出力を求める過程 を図10に示す。このようにしで得られた $\hat{U}(n T)$ はサ イリスタを制御する。ここでは，操作量は偏差，偏 差の微分值および時間の関数で，溶接プロセス中に 適応アルゴリズムの計算がオンラインで実行される FACの情報処理と計算アルゴリズムのソフトのフロ ーチャートを図11に示す。

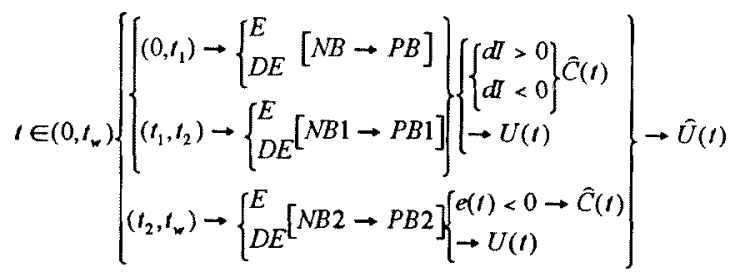

図10 ファジィ適応コントローラの出力算出過程 Fig. 10 Flowchart of output of FAC

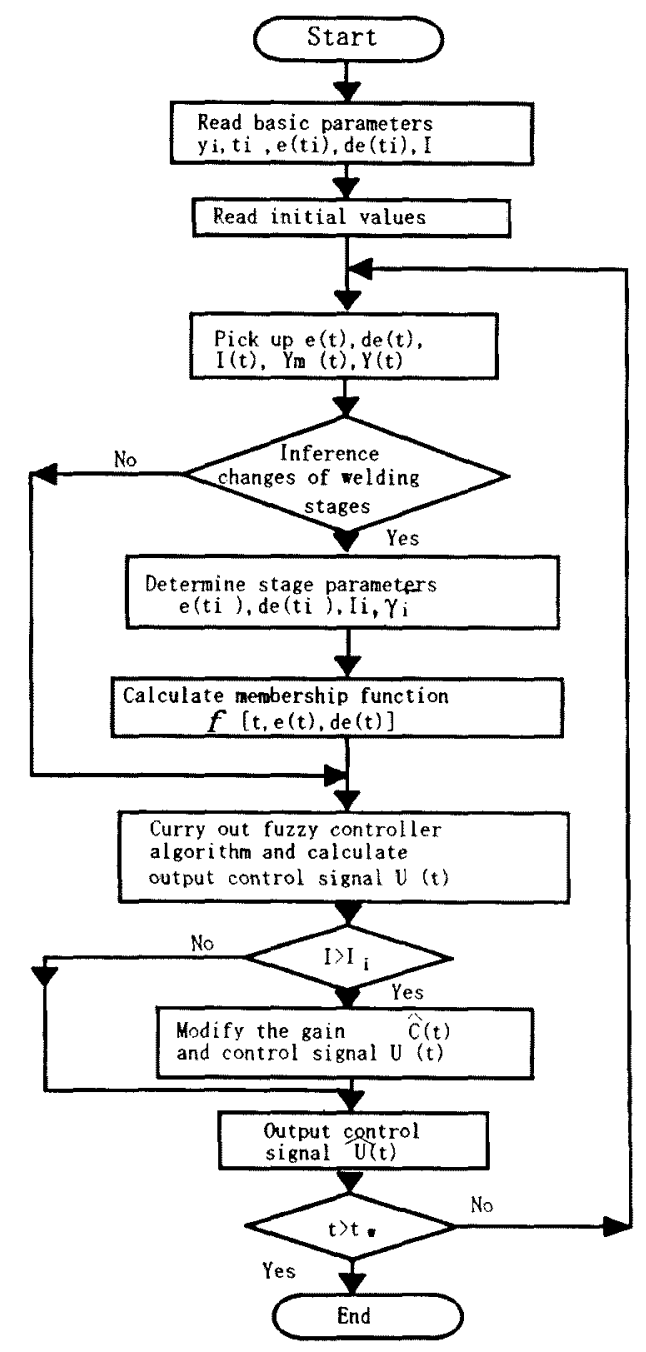

图11 ファジィ適忘コントローラのフローチャート Fig. 11 Flowchart of FAC 


\section{3 実験結果上検討}

ここでは， $2.0 \mathrm{~mm}$ の軟銅板2枚の抵抗スポット溶 接のダミーの電気回路を用いて、シミュレーション と実験を行った。溶接条件を次式に示す。

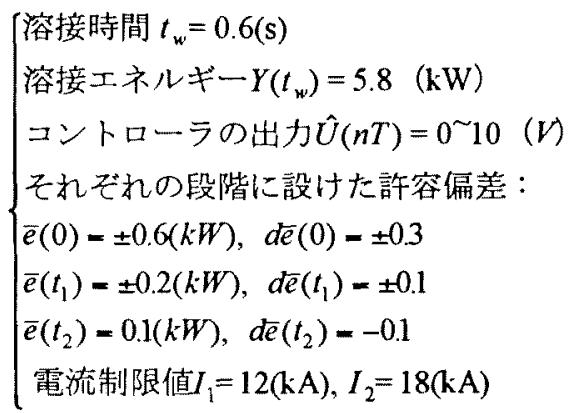

他の条件が同じ場合，普通のFCとFACをそれぞ れ用いて、シミュレーションを行った，FCのメン バシップ関数は，普通の方法のとおり，最大の許容 誤差によってファジィ集合区間を設ける. FCのメ ンバシップ関数は, FACの溶接初期のものと同じ関 数を用いている。图12にシミュレーションの結果を 示す． FCと $\mathrm{FAC}$ 用いた場合の制御特性を比べる と、溶接初期の誤差は両者に変わりがないが，溶接 中期と終期の誤差はFCの誤差が大きくなっている. FACの場合は，溶接中期に溶接の質が保証され，溶 接終期に電力損失が少なくなり，適当なナダットの 溶け込みが得られる。図13にダミ一回路を用いたス ポット溶接機のファジィ適応制御の実験結果を示す。

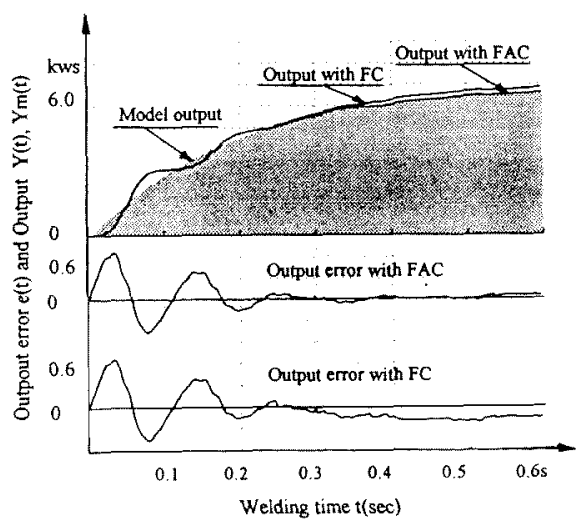

図12 スポット溶接プロセスのシミュレーション

Fig. 12 Simulation of control process for spot welding

また，外乱（電源電圧変動）に対する実験も行っ た。普通，電源電圧 $v(t)$ が減少すると出力エネルギ 一も降下する.ファジィ適态制御の場合, ファジィ 適応コントローラの出力を自動調節し，電流を適応 制御し、プラント出力（エネルキー）の降下を押さ えることができ，制御出力補僙の效果をも有してい ることが，図14の実矣結果よりわかる，電源電圧が
20\%下がっても4サイクル後には，一2\%の精度で目 標值に追従しているのがわかる。

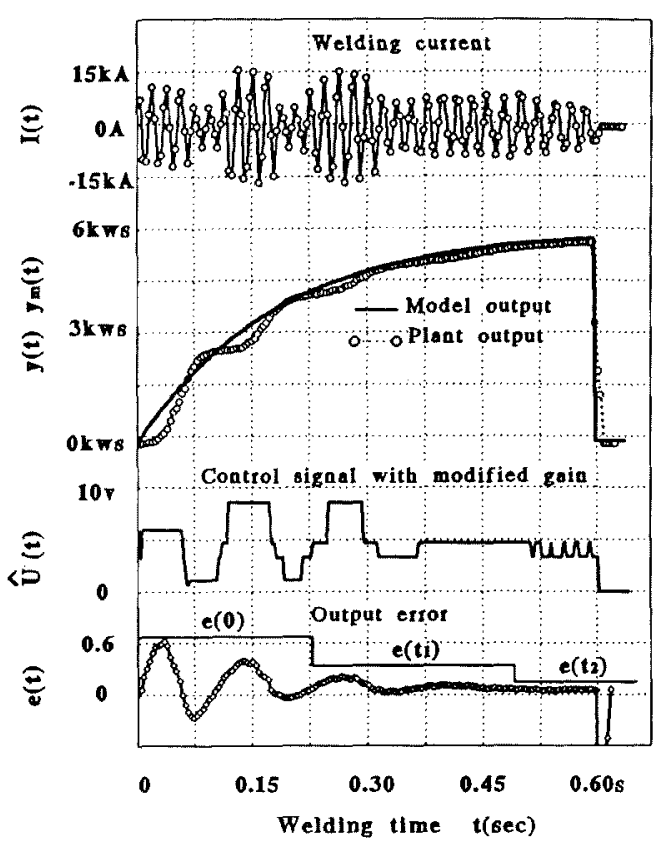

図13溶接プロセスの実験結果（ダミ一回路使用） Fig. 13 Experimental results of control process for spot welding (with a dummy circuit)

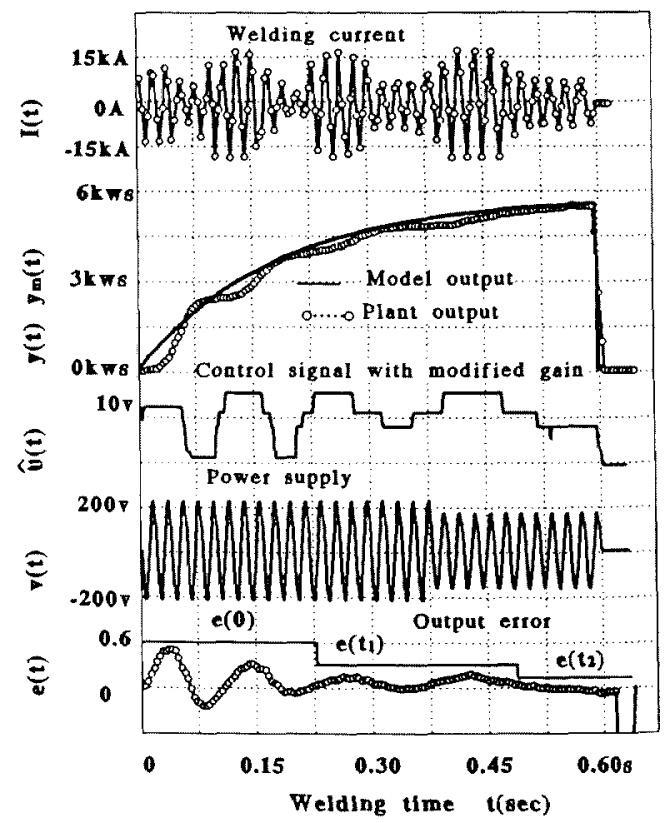

図14溶接機の電源電圧変動に対する応答実験

Fig. 14 Experimental results of anti-disturbance for power source variation of spot welding 
以上の実験結果より,ファジィ適応コントローラ を用いて, 溶接の初期に応答が早く, 中期に偏差が 小さく, 後期に偏差が小さく電力損失の小さい制御 が行われ，小さなエネルギー損失で良好なナゲット が得られることがわかった. 電源電圧の変動に対し ても, 出力の変動を押さえることができ, 外乱を打 ち消す効果（ロバスト性）もあることがわかった。

\section{6. おわりに}

本論文では，先ず，同じ投入溶接エネルギーに対 し, 可変電力溶接が定電流溶接, 定電力溶接に比べ て大きなナゲットサイズの得られること, 溶け込み が適当であることを明らかにした．この可変電力特 性より規範エネルギーモデルを作成した。また，こ の規範モデルを用いて, 抵抗スポット溶接機のモデ ル規範形ファジィ適応システムを構築し, 損失エネ ルギーの少ない, 全プロセスの各段階にわたって指 定した精度を保持する実時間制御が行えた。更に, このシステムについて，シミュレーションと実時間 制御を行い，以下のことを明らかにした。

1) 適応ファジィコントローラを用いれば, 溶接プ ロセスの各段階でメンバシップ関数が調節され, 各 段階での応答が改善され, 過渡状態（溶接初期）に 応答が良くかつ溶接中期と終期に偏差が小さくでき ることがわかった.

2) 溶接機電源電圧の変動に対して, ファジィ適応 コントローラは適応的に制御出力を調節するので, ロバストな制御系が実現できた。

\section{謝辞}

本研究を進めるに当たって, 定置型抵抗スポッ 卜溶接機をご提供戴いた(株)電元社製作所亀谷栄次 社長に謝意を表します。また，スポット溶接の技術 についてご指導を頂いた古館正人技術開発部長なら びに開発部上野和重氏に厚く御礼申し上げます。

(平成8年8月 14 日受付，平成9年3月19日再受付)

\section{参考文献}

(1) 日本溶接協会: スポット溶接入門, 産業出版, 1986.

(2) 松山欽一：軟鋼抵抗スポット溶接におけるナゲ ット安定確保のための入熱投与形態制御とその効果. 電気溶接部会技術委員会, EW17-28-92.

（3）西口公之, 松山欽一：簡易モデルによる処理速 度の高速化数值計算モデルを利用した抵抗スポット 溶接用ナゲット径モニタについて. 溶接学会春季全 国大会講演概要集, Vol. 48, pp. 203,1991 年.

(4) 陳星橋, 荒木嘀次 : 抵抗スポット溶接のパワー モデル,溶接学会, 平成 7 年講演概要第 56 集, pp $162-163$
(5) 陳星橋, 荒木獻次他：抵抗スポット溶接のファ ジィ制御シミュレーション, 溶接学会, 平成 7 年春 季全国講演概要第56集, pp. 164-165

(6) 安信 誠二：ファジィ工学; 昭晃堂,1993

(7) Okyay Kaynak and Imre Rudas: Applications of Soft Computing Methodologies in Mechatronics. Proc. of Asian Control Conference 1994, 53/56

(8) 管野 道夫：ファジィ制御; 日刊工業新聞,1990

(9) H. Takahasi, et al.: Application of a Self-tuning Fuzzy Logic System to Automatic Speed Control Devices; Proc. of 26th SICE Annual Conference II , 1241/1244 (1987)

(10) I.D.Landau and M.Tomizuka: Theory and Practice of Adaptive Control Systems, 1979.

(11) E. H. Mamdani: Applications of Fuzzy Algorithms for Control of Simple Dynamic Plant; Proc. IEE, Vol.121, No.12, 1585/1588(1974)

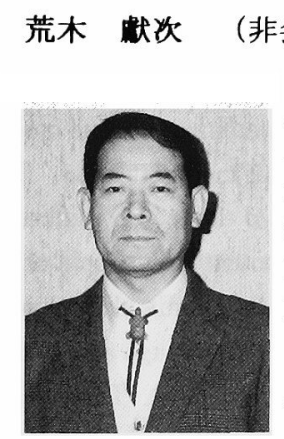

(非会員) 1958 年 横浜国立大学工 学部機械工学科卒業. 1962 年 東京大学生産技術研究所 助手, 1966 年同講師, 1970 年 埼玉大学工学部 機械工学科助 教授, 1984 年同教授, 現在に 至る. 1975 年台湾清華大学招 聘教授. 油空圧制 御システム の知能化, 人間支援工学, 適 応制御, 抵抗スポット溶接機 の制御, 制御機器の開発等の 研究に従事. 工学博士（1970, 東京大学）。1989 年 度油空圧機器技術振興財団学術論文顕彰, 1996 年 度日本油空圧学会学術論文賞を受賞. 日本油空圧学 会, 計測自動制御学会, 日本機械学会の会員.

陳 星橋 (学生員) 1988年中国鉣業大学大学 院電気工学専攻修士課程 修了,

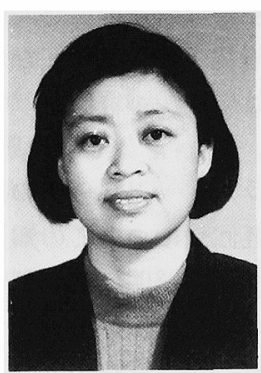
同年専任講師。ファジィ工学, 適応制御および知能制御の理 論と応用の研究に従事. 1994 年埼玉大学大学院理工学研究 科博士後期課程入学, 現在に 至る。適応制御を中心とした 制御理論およびその抵抗スポ ット溶接システムへの応用に 関する研究に従事. 電気学会, 計測自動制御学会, 溶接学会 学生会員. 